Carbon Vol. 35, No. 3, pp. 403-410, 1997

Copyright 01997 Elsevier Science Ltd

Printed in Great Britain. All rights reserved

000E-62231\$9177.00+ 0.00

\title{
INFLUENCE OF SURFACE IONIZATION ON THE
}

ADSORPTION OF AQUEOUS ZINC SPECIES BY ACTIVATED

\section{CARBONS}

P. J. M. CARROTT,* M. M. L. RIBEIRO CARROTT, J. M. V. NABAIS and

J. P. PRATES RAMALHO

Departamento de Quimica, Universidade de 1\&or?, Coltgio Luis Antbnio Verney, Rua RomSo Ramalho, 59

7000 Evora, Portugal

(Received 30 July 1996; accepted in revised form 30 October 1996)

Abstract-A surface ionization and adsorption model is used to simulate the adsorption of zinc species

from aqueous solutions of varying $\mathrm{pH}$ on a number of different activated carbons and the results

compared with experimental data. In all cases good agreement is obtained between theory and experiment.

It is shown that for most of the carbons the uptake of zinc is due to adsorption of $\mathrm{Zn}^{*}+$ ions on ionized

acid sites, the calculated equilibrium constants being of the order of 10 "107. On the other hand, one of

the carbons used (NORIT AZO) contains virtually no acid sites, but a high concentration of strong

basic sites, and the uptake of zinc in this case appears to be due to adsorption of a negatively charged

hydroxy complex on protonated basic sites, the estimated equilibrium constant being 10'. 01997 Elsevier

Science Ltd. All rights reserved

Key Words-A. Activated carbon, adsorption, C. molecular simulation, D. surface properties. 